\title{
Sikap Over Proteksi Orang Tua Dan Kematangan Sosial Anak
}

\author{
Oleh: \\ Uswatun Hasanah \\ (Program Studi Pskologi Islam Istitut agama Islam Tribakti Kediri)
}

\begin{abstract}
Abstrak
Penelitian ini bertujuan mencari hubungan sikap over proteksi orang tua dengan kematangan sosial anak PAUD. Over proteksi sebagai variabel bebas dan variabel tergantungnya yaitu kematangan sosial anak. Subyek dalam penelitian adalah seluruh murid PAUD. yang berjumlah 40 anak. Data penelitian ini dianalisis dengan tehnik statistik Produc Moment. Hasil Analisis didapat nilai indek korelasi $r x y-0,334 ; P=0,033(P<0,05)$ yang artinya terdapat Hubungan negatif yang siginifikan antara Sikap Over Proteksi Orang tua dengan Kematangan Sosial Anak. Metode pengumpulan data yang digunakan dalam penelitian ini adalah angket untuk mengukur skala pola asuh Over proteksi digunakan skala yang dikembangankan oleh peneliti sendiri, Sedang untuk mengukur Kematangan Sosial Anak menggunakan The Vineland Social Maturity Scale. Kesimpulannya adalah ada hubungan yang signifikan antara Pola Asuh Over Proteksi dengan Kematangan Sosial Anak.
\end{abstract}

Kata Kunci: Sikap over proteksi orang tua, Kematangan Sosial

This study aims to find the relationship over protective attitude of parents with children early childhood social maturity. Over protection as independent variables and the dependent variable is the social maturity of the child. Subjects in the study were all students of early childhood education. totaling 40 children. Data were analyzed with statistical techniques Produc Moment. Analysis results obtained index value correlation $r x y-0.334 ; P=0.033$ $(P<0.05)$, which means there is a significant negative 
relationship between Attitude Over Protection Parents with Children's Social Maturity. Data collection methods used in this study was a questionnaire to measure the scale of parenting Over protection used scale dikembangankan by the researchers themselves, Average to measure using the Children's Social Maturity The Vineland Social Maturity Scale. The conclusion is that there is a significant relationship between Parenting Over Child Social Protection at Maturity.

Keywords: Attitude over protection of the elderly, Social Maturity

\section{Pendahuluan}

Keluarga merupakan lingkungan primer yang dikenal oleh anak, Hubungan orang tua-anak dan anggota keluarga lain dapat dianggap sebagai suatu sistem atau bagian jaringan sosial yang lebih kecil dalam interaksi sosial (Bronfenbrenner dalam Mussen, dkk., 1992). Nilai-nilai dan norma sosial yang ditanamkan oleh orang tua melalui perlakuan dan pola asuh yang diterapkan kepada anak merupakan sarana pengkondisian anak terhadap nilai-nilai dan norma-norma sosial yang berlaku dalam lingkungan sosial orang tua, sehingga nilai-nilai ini akan menjadi dasar bagi anak untuk berperilaku dalam perkembangan selanjutnya. Pola asuh atau sikap orang tua tidak hanya mempunyai pengaruh kuat pada hubungan di dalam keluarga tetapi juga pada sikap dan perilaku anak termasuk kemandirian dan kematangan sosial.

Sering kita temui sikap orang tua yang terlalu over protek berlebihan terhadap dengan alasan klasik terlalu sayang sehingga mereka melindungi anak terlalu berlebihan, kekhawatiran yang berlebihan terhadap apa saja yang dilakukan anak, banyak memberikan batasan-batasan, sehingga anak lebih tidak memiliki kesempatan untuk berekplorasi dengan lingkungan disekitarnya sehingga menjadi anak yang tidak matang dan kurang percaya diri. Orang tua yang tidak terlalu melindungi atau tidak terlalu posesif terhadap anak, mendorong anak untuk mandiri dan percaya diri. Mandiri dan percaya diri merupakan dua kualitas yang sangat mendukung kemampuan sosial anak. Ada sebagian orang tua yang menerapkan kontrol yang kuat kepada 
anaknya, memberikan perhatian yang berlebihan atau terlalu over proteksi sebagai rasionalisasi pengekangan anak, komunikasi diberikan sebagai perintah bukan penjelasan.

Bryne, Baron dan Kantowizt (1980) menyatakan bahwa pola asuh dalam keluarga sangat berpengaruh dalam perkembangan kepribadian seorang anak sikap perhatian orang tua yang otoriter dan over proteksi terhadap anak akan mempengaruhi perkembangan kepribadian dan inteligensi seseorang anak.

Pada dasarnya masa awal perkembangan ketrampilan bersosialisasi, kemandirian, kepercayaan diri itu berasal dari lingkungan dan hasil didikkan orang tuanya.Tampak pola penerapan kontrol, komunikasi dan perhatian orang tua kepada anaknya akan mempengaruhi kematangan sosial anak.

Berdasarkan uraian diatas, maka dalam penulisan ini diajukan hipotesis sebagai berikut "ada hubungan antara pola asuh Overproteksi Orang tua dengan kematangan sosial anak PAUD ".

\section{Metode Penelitian}

Jumlah subyek dalam penelitian ini adalah 40 anak. Teknik pengambilan sampel penelitian adalah purposive random sampling yaitu pengambilan sampel berdasar ciriciri yang telah ditetapkan. Adapun ciri-ciri yang ditetapkan siswa PAUD yang berjumlah 40 siswa yang berusia 3- 7 tahun, di PAUD

Variabel-variabel yang dikaji dalam penelitian ini meliputi: Variabel Bebas $\mathrm{X}$ : Pola asuh over proteksi; Variabel Terikat Y: Kematangan sosial anak. Pola asuh over proteksi adalah sikap dan perlakuan orang tua kepada anak dalam kehidupan sehari-hari, yang diwujudkan dalam bentuk pemberian kontrol, perhatian dan kasih sayang yang terlalu berlebihan kepada anak. Hal ini dapat dilihat dari cara orang tua menunjukkan sikap yang terlalu berhati-hati terhadap anak, khawatir akan keselamatan anak, khawatir akan kesehatan anak, khawatir akan kegagalan anak. Variabel ini akan diungkap dengan skala pola over proteksi.

Kematangan sosial, adalah kemampuan anak dalam melakukan tugas, menyesuaikan diri, mengikuti aturan- 
aturan, mengarahkan diri dan memahami norma-norma sosial sesuai dengan tingkat usianya. Variabel ini akan diukur dengan menggunakan Vineland Social Maturity Scale.

Teknik pengambilan data yang digunakan dalam penelitian ini meliputi:

\section{Vineland Social Maturity Scale}

Untuk mengukur kematangan sosial anak digunakan Vineland Social Maturity Scale. Menurut Doll E.A. skala ini telah dipublikasikan sejak tahun 1936 dan dirancang untuk menilai kematangan sosial seseorang sejak masa bayi sampai individu itu mencapai usia 30 tahun. The Vineland Maturity Scale merupakan suatu alat ukur berbentuk inventory yang digunakan untuk mengukur tingkat kematangan sosial anak. Inventory, yaitu berupa sejumlah pernyataan yang sudah disediakan beberapa alternatif jawaban, dimana subyek harus memilih salah satu dari jawaban yang tersedia.

Versi kelas untuk anak usia 3-12 dapat diisi oleh guru. Ketrampilan pribadi dan sosial yang dievaluasi meliputi bidang-bidang berikut: ketrampilan sehari-hari (menolong diri secara umum, makan, berpakaian); komunikasi (mendengar, berbicara, menulis); ketrampilan motorik (halus dan kasar, termasuk lokomosi); sosialisasi (hubungan antar pribadi, bermain dan mengisi waktu luang, serta ketrampilan coping); ketrampilan kerja; dan pengarahan diri. Tes ini tidak dibatasi waktu, namun biasanya berlangsung antara 20-30 menit. Skor-skor kasar dikonversi ke skor yang ekuivalen (dinyatakan sebagai usia sosial) dan suatu social quotien.

Skala ini juga dapat dipakai sebagai pengganti pemeriksaan psikometrik bila oleh sesuatu hal pemeriksaan ini tidak dapat dilakukan (misalnya: adanya kesukaran bicara, kerusakan koordinasi syaraf-otot, karena budaya yang berbeda, atau karena individu yang diperiksa tidak dapat didatangkan). Dari beberapa penelitian diungkapkan bahwa ada hubungan antara umur sosial (Social Age =SA) dan umur mental (Mental Age = MA). Hasil pengukuran SA ini valid bila tidak ada pengaruh lain di luar kecerdasan (seperti kelumpuhan, gangguan emosi, faktor-faktor situasi). Bila ada faktor lain ini maka diperlukan teknik yang berbeda. 
Menurut manualnya skala ini memberikan garis besar performans terperinci yang menunjukkan kemajuan kapasitas anak dalam pemeliharaan diri dan dalam partisipasi yang menuju perkembangan orang dewasa yang berdikari. Butirbutir performans disajikan menurut taraf kesukarannya dan menggambarkan kemajuan kematangan menolong diri sendiri, mengarahkan diri sendiri, bepergian, pekerjaan atau kesibukan, komunikasi dan hubungan sosial. Kematangan dalam berdikari dalam kehidupan sosial adalah ukuran perkembangan menuju kemampuan sosial yang lebih tinggi.

Kegunaan skala ini adalah: merupakan jadwal standar perkembangan normal yang dapat dipakai untuk membandingkan dan mengukur perkembangan atau perubahan perkembangan, mengukur perbedaan individual, mengukur penyimpangan yang dapat digunakan untuk mendeteksi kelemahan mental, kenakalan anak-anak, penempatan anak atau adopsi anak, sebagai indeks kualitatif yang menunjukkan perbedaan perkembangan subyek abnormal, yang tidak stabil, yang psikopatik, dan yang epileptik, sebagai ukuran perbaikan hasil perlakuan khusus, terapi, atau latihan-latihan, sebagai jadual melihat kembali sejarah perkembangan dalam penelitian klinis mengenai keterlambatan perkembangan, penurunan, dan tingkat perkembangan.

Skala ini dapat digunakan untuk membedakan retardasi mental yang disertai inkompetensi (feeble minded) dan retardasi mental tanpa inkompetensi sosial (yang sering diduga sebagai feeble minded). Skala ini juga membantu bimbingan dan latihan anak dengan menunjukkan aspek yang mana yang memerlukan bimbingan. Jadi sekali lagi ini dapat merupakan cara evaluasi pengaruh lingkungan, status kebudayaan, dan akibat dari cacat seperti buta, tuli, dan lumpuh terhadap perkembangan kompetensi sosial.

The Vineland Social Maturity Scale mengukur kompetensi sosial, ketrampilan menolong diri (self-help), dan tingkahlaku adaptif dari masa bayi sampai orang dewasa. Skala ini digunakan untuk mengukur terapi dan/atau pengajaran individual untuk orang-orang yang mengalami retardasi mental atau gangguan emosional. The Vineland 
Social Maturity Scale dapat digunakan dari sejak anak lahir sampai usia 30 melalui wawancara dengan orang tua atau pengasuh anak. Skala ini terdiri dari 117 item terbagi menjadi delapan dimensi sebagai indikator kematangan sosial.

a. Dimensi-dimensi kematangan sosial

1) SHG, Self Help Generally (kemampuan untuk mengurus diri sendiri secara umum)

2) SHE, Self Help Eating (kemampuan untuk makan sendiri)

3) SHD, Self Help Dressing (kemampuan untuk berpakaian sendiri)

4) SD, Self Directtion (kemampuan untuk mengarahkan diri)

5) $\mathrm{O}$, Occupation (kemampuan untuk bekerja dan beradaptasi dengan waktu)

6) L, Locomotion (kemampuan untuk melakukan gerakan)

7) C, Communication (kemampuan untuk berkomunikasi)

8) S, Socialization (kemampuan untuk menjalin hubungan sosial).

\section{b. Sistem Skoring}

Tiap-tiap item dalam Vineland Social Maturity Scale diberi skor/nilai antara 0 - 4:

1) Skor 0: bila anak tidak mampu melakukan sama sekali

2) Skor 1: bila anak kurang mampu melakukan sehingga hasilnya kurang baik

3) Skor 2: bila anak mampu melakukan dengan hasil hampir cukup baik (berdasar keterangan atau tidak melihat langsung)

4) Skor 3: bila anak mampu melakukan dengan hasil cukup baik

5) Skor 4: bila anak mampu melakukan secara baik dengan hasil memuaskan

\section{c. Standardisasi}

Pengumpulan data untuk standardisasi norma dilakukan dengan jumlah sampel seluruhnya 620 subyek, dengan rentang usia sampai 30 tahun. Pada tiap-tiap jenjang usia diambil 20 orang subyek, masing-masing 10 orang untuk setiap jenis kelamin (laki-laki 10 orang dan perempuan 10 orang). Dilihat dari jumlah sampelnya, ini merupakan sampel 
yang terlalu kecil untuk standardisasi. Namun harus diingat bahwa standardisasi menggunakan kalibrasi data dari subyek yang lebih tua dalam tenggang beberapa tahun. Standardisasi yang demikian stabilitasnya ditentukan oleh konsistensi internal secara keseluruhan.

Skor yang diperoleh pada skala ini bukan bersifat selfreport dari subyek, namun berdasarkan informasi sekunder dari seorang rater yang dekat dengan subyek, seperti ibu, bapak, teman terdekat, pengasuh, pengawas, dan penjaga atau pengawas.

\section{Skala Pola Asuh}

\section{a. Penyusunan Skala Pola Asuh Overproteksi}

Teori yang digunakan untuk menyusun skala ini adalah teori pola asuh dari Baumrid (Halim, 1994) Dasar teori pola asuh over proteksi orang tua yang dikemukakan Kartono (1986) meliputi indikator-indikator: a) Orang yang terlalu berhati-hati dalam hal pendidikan b) Senantiasa menjaga keselamatan anak c) Orang tua yang terlalu bertindak berlebihan menghindarkan anak dari berbagai bahaya. d). Berdasarkan indikator tersebut skala ini dikembangkan menjadi item-item seperti pada tabel blue print skala sebagai berikut:

Tabel 1 Blue print skala Pola Asuh Overproteksi

\begin{tabular}{|c|c|c|c|c|}
\hline \multirow[b]{2}{*}{ No. } & \multirow[b]{2}{*}{ Indikator } & \multicolumn{2}{|c|}{ Nomor dan Jenis Item } & \multirow[b]{2}{*}{ Total } \\
\hline & & Favourable & Unfavourable & \\
\hline 1. & $\begin{array}{l}\text { Terlalu berhati-hati } \\
\text { pada anak }\end{array}$ & $\begin{array}{c}5,11,12,14,17,1 \\
9,20 \\
22,27,32,37,3 \\
9,41\end{array}$ & $\begin{array}{c}4,13,16,25,28 \\
42,43\end{array}$ & 20 \\
\hline 2. & $\begin{array}{l}\text { Khawatir akan } \\
\text { keselamatan anak }\end{array}$ & $\begin{array}{c}1,2,3,15,23,29 \\
31,44\end{array}$ & 9,30 & 10 \\
\hline 3. & $\begin{array}{l}\text { Khawatir akan } \\
\text { kesehatan }\end{array}$ & $33,34,35,40$ & 21,45 & 6 \\
\hline 4. & $\begin{array}{l}\text { Khawatir akan } \\
\text { kegagalan anak }\end{array}$ & $8,18,24,36$ & $6,7,10,26,38$ & 9 \\
\hline & Jumlah & 29 & 16 & 45 \\
\hline
\end{tabular}




\section{b. Sistem Skoring Skala Pola Asuh}

Format skala ini dikembangkan dengan berdasarkan skala sikap Likert, dengan bentuk lima pilihan jawaban yang bersifat close ended quesionare, yaitu suatu bentuk pilihan dengan butir-butir pernyataan yang telah ditentukan jawabannya. Respon jawaban terdiri 5 (lima) skala dari sangat setuju (SS), setuju (S), tidak setuju (TS) dan sangat tidak setuju (STS). Butir item tersebut terdiri dari pertanyaan positif (favourable) dan pertanyaan negatif (unfavourable).

Tabel 2 Sistem Skoring Item Berdasarkan jenisnya

\begin{tabular}{lcl}
\hline \multicolumn{1}{c}{ Favourable } & Skor & \multicolumn{1}{c}{ Unfavourable } \\
\hline Sangat Tidak Setuju & 1 & Sangat Setuju \\
Tidak Setuju & 2 & Setuju \\
Setuju & 3 & Tidak Setuju \\
Sangat Setuju & 4 & Sangat Tidak Setuju \\
\hline
\end{tabular}

Semakin tinggi skor yang diperoleh, maka semakin ketat penerapan kontrol, perhatian, dan komunikasi yang diberikan orang tua kepada anak.

\section{c. Validitas Skala Pola Asuh Over Proteksi}

Untuk menguji validitas skala pola asuh Over Proteksi menggunakan komuter Seri Program Statistik (SPS-2000) Edisi Sutrisno Hadi dan Yuni Pamardiningsih Modul Analisis Butir Program Kesahian butir.

Item dalam skala ini berjumlah 45 butir, dari hasil uji validitas diperoleh 39 butir item valid. Jumlah butir item yang dinyatakan gugur sebanyak 11 item yaitu: 1, 5, 10, 12, 20, 21, $23,25,30,35,43$. Item tersebut dinyatakan gugur karena koefesien korelasi $r$ hasil hitung mempunyai peluang ralat $(p)$ lebih besar dari 0,005. Indeks masing-masing aspek dapat dilihat pada tabel berikut ini:

Tabel 3 Indeks Validitas Skala Pola asuh Overproteksi

\begin{tabular}{clc}
\hline No. & \multicolumn{1}{c}{ Indikator } & Indeks Validitas \\
\hline 01. & Terlalu berhati-hati pada anak & $0,256-0,674$ \\
O2. & Khawatir akan keselamatan & $0,378-0,620$ \\
O3. & Khawatir akan kesehatan & $0,292-0,527$ \\
04. & Khawatir akan kegagalan & $0,340-0,622$ \\
\hline
\end{tabular}




\section{d. Reliabilitas Skala Pola Asuh Over proteksi}

Untuk mengetahui koefisien reliabilitas Skala Pola asuh Over Proteksi digunakan uji keandalan tehnik Hoyt dari modul analisis butir Seri Program Statistik (SPS-2000) Edisi Sutrisno Hadi dan Yuni Pamardiningsih Universitas Gadjah Mada.

Hasil analisis realiabilitas item valid tiap-tiap aspek dapat dilihat pada tabel di bawah ini.

Tabel 4 Indek Reliabilitas skala Sikap Overproteksi Orang Tua

\begin{tabular}{clcc}
\hline No. & \multicolumn{1}{c}{ Indikator } & rtt & P \\
\hline 01. & Terlalu berhati-hati pada anak & 0,892 & 0,000 \\
02. & Khawatir akan keselamatan & 0,813 & 0,000 \\
03. & Khawatir akan kesehatan & 0,640 & 0,000 \\
04. & Khawatir akan kegagalan & 0,770 & 0,000 \\
\hline
\end{tabular}

Penelitian ini dilakukan mulai tanggal 10 Januari sampai dengan 16 Februari 2016,sebelum penelitian dilaksanakan ,terlebih dahulu peneliti mempersiapkan alat ukur penelitian , The Vineland Social Maturity Scale Setelah perlengkapan tersedia, selanjutnya peneliti mendata murid PAUD tersebut sejumlah 40 anak. Selanjutnya data penilaian didapat oleh peneliti melalui observasi dan wawancara dengan orang tua atau pengasuh anak dan terhadap kemampuan yang telah dikuasai anak. Skala ini terdiri dari 117 item terbagi menjadi delapan dimensi sebagai indikator kematangan sosial. Penilaian skala VSMS diambil sesuai usia anak dimulai dari skala usia sebelumnya dan sesudahnya. Selanjutnya untuk angket skala pengukuran over proteksi diisi oleh orang tua anak.

Tujuan dari analisis data adalah untuk menyederhanakan data tersebut ke dalam bentuk yang mudah dibaca dan diinterpretasi. Dalam proses ini, analisis yang digunakan adalah statistik parametrik, tetapi sebelum melakukan analisis dengan statistik parametrik maka perlu dipenuhi beberapa syarat dasar atau asumsi-asumsi penggunaan analisis statistik parametrik. 
Metode analisis data yang digunakan dalam penelitian ini adalah metode statistik korelasi Product Moment. Metode ini merupakan suatu teknik statistik yang memungkinkan penyelidik melihat hubungan antara variabel bebas $X$ terhadap variabel terikat $\mathrm{Y}$.

\section{Hasil Penelitian dan Pembahasan}

Hasil penelitian berupa hasil analisis korelasi product moment antara variabel pola asuh over proteksi orang tua dengan kematangan sosial anak, yang dilakukan dengan analisis korelasi momen tangkar (product moment) dari Karl Pearson dengan jumlah subyek $N=40$ diperoleh hasil sebagai berikut dalam tabel dibawah ini:

Tabel 5 Hasil Analisis Korelasi Product Moment

\begin{tabular}{ccccc}
\hline Subyek & Sumber & $\begin{array}{c}\text { Indeks } \\
\text { Korelasi }\end{array}$ & P & Keterangan \\
\hline 40 & $r x y$ & $-0,334$ & 0,033 & Signifikan \\
\hline
\end{tabular}

\section{Pembahasan}

Hasil analisis korelasi didapat nilai $r x y=-0,334$ dan $\mathrm{P}=$ $0,033(\mathrm{P}<0,05)$ menunjukkan bahwa ada hubungan negatif yang signifikan antara pola asuh over proteksi $(\mathrm{X})$ dengan kematangan sosial $(\mathrm{Y})$ pada anak-anak PAUD.

Artinya semakin tinggi pola asuh over proteksi maka semakin rendah tingkat kematangan sosial anak. Hal ini menjelaskan bahwa pola pengasuhan orang tua memberikan kontribusi yang signifikan terhadap perkembangan kematangan sosial anak-anak usia prasekolah.

Anak usia prasekolah adalah anak yang berusia tiga sampai enam tahun, seiring pertumbuhan anak, dimensi eksternal anak prasekolah juga berubah, umumnya anak pada usia ini mulai memasuki awal prasekolah dan kindergarden dimana anak dituntut menjalankan serangkaian aturan baru didorong untuk beradaptasi serta bersosialisasi dengan orang disekitarnya.

Mendidik adalah kewajiban yang harus dilakukan orang tua guna mendorong anak untuk mencapai kematangan sosial terutama pada anak usia pra sekolah pola hubungan orang tua dengan anak menjadi salah satu faktor yang 
mempengaruhi perkembangan psikologis dan sosial anak. Stimulus dan respon orang tua yang sesuai dengan perkembangan anak akan mendorong perkembangan psikologis dan sosial anak sebaliknya stimulus dan respon yang tidak sesuai dengan kebutuhan anak akan menghambat perkembangan anak. Mussen, dkk (1992) menyatakan bahwa orang tua merupakan agen sosialisasi yang paling penting bagi anak-anak, lebih jauh lagi sosialisasi anak dalam keluarga merupakan proses dua arah meliputi sifat anak dalam berinteraksi serta karakteristik dan praktek perawatasuhan anak oleh keluarga.

Pola asuh orang tua yang terlalu overproteksi atau terlalu dilindungi orang tua karena sikap orang tua yang terlalu khawatir pada anaknya, secara umum anak tidak mampu melakukan tugas-tugas yang seharusnya dapat dilakukan sendiri sesuai usianya bila anak senantiasa terus dibesarkan dalam perlindungan berlebihan, lama kelamaan anak akan membangun rasa takut yang tidak wajar terhadap keraiman sekolah (School Phobia) atau Fobia keramian (Erythophobia) ini merupakan kekhasan pada anak -anak yang mendapatkan perlindungan yang berlebihan, Ayahbunda(1998). Selama anak masih kecil selalu ditakuttakuti dengan rasa yang menakutkan maka anak akan kurang percaya diri dan juga apalagi keinginan anak untuk mencoba segala sesuatu harus selalu tidak diperbolehkan, maka akan membuat anak tidak punya kesempatan percaya terhadap dirinya. Sehingga hal ini akan membawa rasa minder atau takut terhadap anak tersebut dalam menghadapi segala sesuatu yang ia inginkan. Keberanian anak memang dimulai sejak dini dengan dibiasakan rasa percaya diri yang kuat untuk menjadikan akan mampu menghadapi segala yang ia hadapi dan anak akan merasa percaya diri dan menjadikan anak mantap. (Lukman,1999).

Yang termasuk perlindungan berlebihan (Over proteksi) dalam hal ini adalah memanjakan, memenuhi segala sesuatu yang diinginkan, dan mencampuri segala kewajiban dan tanggung jawab si anak. Pada dasarnya, sikap merampas keinginan anak untuk mandiri. (Rasyid, 2008). 
Pola pengasuhan orang tua mempunyai peran yang signifikan pada proses perkembangan kepribadian anak-anak. Pola asuh dan perlakuan orang tua terhadap anak merupakan sarana pengkondisian anak dalam membentuk kepribadiannya. Orang tua, merupakan pihak yang memiliki hubungan paling dekat dan mendalam dengan anak, baik secara fisik, psikologis dan sosial, dan dari orang tua-lah anak mendapat dasar-dasar yang kuat bagi perkembangan diri selanjutnya, termasuk hal-hal yang berkaitan dengan perkembangan emosi dan sosial. Proses kematangan yaitu berfungsi sebagai hasil dari suatu keberhasilan dan berlalunya satu fase perkembangan. Setiap anak mendapat implus untuk berkembang dengan caranya sendiri,untuk melatih semua bakat dan kemampuanya segala sesuatu yang sudah dicapai oleh anak,dijadikan persiapan atau titik tolak ukur baru bagi pengalaman dan kemampuan berikutnya, dimana setiap gejala baru dapat dijelaskan berdasarkan perkembangan sebelumnya.

Perkembangan sosial merupakan pencapaian kematangan dalam hubungan sosial. Dapat juga diartikan sebagai proses belajar untuk menyesuaikan diri terhadap norma, kelompok moral dan tradisi. Mendidik anak merupakan kewajiban orang tua dalam keluarga yang dilakukan dengan cara melakukan pendekatan pada anak dan membantu mencari solusi terhadap kesulitan anak-anak dalam belajar. Dengan demikian dukungan sosial orang tua dalam mendidik anak memiliki fungsi sebagai informasi yang membantu anak pra sekolah untuk percaya bahwa mereka selalu diperhatikan untuk mencapai keberhasilan dalam proses belajar.

Berkaitan dengan hal proses belajar anak untuk mengembangkan kemampuan sosialnya, salah satu faktor penentu keberhasilan belajar anak adalah tipe asuh orang tua terhadap anaknya. Tipe pola asuh yang dianggap efektif secara psikologi dan sosiologis adalah orang tua yang dianggap efektif secara psikologis adalah orang tua yang dapat menjalin hubungan harmonis dengan anak. Ketidak harmonisan hubungan orang tua dengan anak menunjukan pada dua tipe yaitu orang tua yang bersikap acuh dan apatis 
terhadap perkembangan anak dan orang yang bersikap memanjakan yang sangat melindungi anak dari pengaruh luar. (Arikunto,1996).

Perawatasuhan ini merupakan model dari pengkondisian orang tua terhadap anak menurut standart ideal orang tua. Seorang anak akan mengalami perkembangan sosial lebih dini apabila memperoleh suasana yang kondusif, merasa aman dan bebas secara psikologis. Ditambahkan oleh Indrawati (Kartono, 1985) bahwa aman, artinya tidak mendapatkan tekanan kejiwaan dalam bentuk penilaian, keberadaan anak diterima apa adanya dan diterima dengan segala keunikannya. Sedangkan bebas adalah adanya kesempatan untuk dapat mengekspresikan gagasan-gagasan secara simbolik tanpa terlalu banyak hambatan. Bagi anak-anak, munculnya perasaan ini lebih banyak bersumber dari suasana keluarga atau perlakuan dan pola asuh orang tua. Menurut Ediasri (Gunarsa dan Gunarsa, 1989) suatu didikan atau asuhan yang diberikan, dapat mempengaruhi kemandirian anak, maka jika terdapat sesuatu kesalahan dalam mendidik atau mengasuh akan berakibat tidak baik pula bagi kemandirian anak. Orang tua yang terlalu menyayangi anaknya secara berlebihan seringkali salah dalam memahami bentuk penerapan serta pemberian kasih sayang terhadap anak, sehingga anak diperlakukan sangat terlalu berhati-hati atau terlalu over protek yang bermanifestasi pada bentuk kontrol yang terlalu kuat terhadap segala aktifitas anak karena orang tua tidak mempercayai kemampuan anaknya sehingga anak banyak dibantu dan dilarang atau dibatasi dalam aktifitasnya sehingga kurang memiliki pengalaman dalam mengembangkan perkembangan kematangan sosialnya, sehingga menjadi anak yang tidak mandiri dan kurang percaya diri.

Dewasa ini, jarang sekali bahkan hampir tidak ada orang tua yang menerapkan pola pengasuhan dengan cara-cara konservatif (menekankan dimensi kontrol dan kepatuhan dengan ketat) atau bersifat liberal (memberi kebebasan secara luas kepada anak), Kita mungkin menemukan orang tua yang terus menerus melakukan campur tangan dalam urusan anak. la menjadi pengganti si anak dalam mengerjakan tugas, peran, dan tunggung jawab yang seharusnya dipikul oleh anak. 
Padahal, seharusnya si anak dibidarkan berlatih melakukannya. Dengan demikian, tidak ada kesempatan bagi si anak untuk memilih kegiatan, hubungan-hubungan, makanan, permainannya sendiri, dan seterusnya. Hal ini akan menjadi si anak kurang pengalaman sehingga tidak berdaya untuk melakukan sesuatu yang diinginkannya

Mayoritas keluarga dewasa ini lebih menerapkan pola pengasuhan moderat (kontrol dan kebebasan diberikan secara proporsional). Meningkatkan kesadaran masyarakat terhadap pentingnya perngaruh pola asuh pada perkembangan anak, dan UU tentang Perlindungan Anak kemungkinan ikut mempengaruhi pola berpikir masyakarat. Perubahan pola pengasuhan yang lebih moderat atau demokratis tersebut memberikan kontribusi yang signifikan terhadap perkembangan kematangan sosial pada anak-anak usia prasekolah, Pola asuh orang tua dari segi kontrol yang terlalu over proteksi membawa dampak negatif bagi perkembangan kematangan sosialnya, diantaranya anak menjadi kurang percaya diri, tergantung ,kurang mampu menyesuaikan diri, kurang berani menggambil keputusan, kreatifitasnya kurang berkembang maksimal seperti yang ditemukan dalam penelitian ini.

Harlock (1990) mengemukakan bahwa anak-anak yang dibesarkan dalam keluarga yang demokratis penyesuaian sosialnya paling baik. Anak mudah untuk bergaul dan aktif secara sosial, karena pola asuh demokratis ini orang tua memberikan pengarahan dan penjelasan terhadap tindakan yang dilakukan anak, menghargai keberadaan anak dan memberikan kasih sayang yang tulus, hal akan memberikan rasa aman pada anak. Sebaliknya anak yang dididik secara otoriter, dengan kontrol ketat dan lebih menekankan hukuman daripada rewards cenderung menciptakan anak yang tidak mempunyai kepercayaan diri, pendiam, pasif dan cenderung agresif. Sebaliknya, anak yang tumbuh dalam keluarga dengan kontrol dan perhatian yang tidak memadai (sangat longgar) cenderung menjadi anak egois, apatis, penuh keraguan (ambivalen), sering menentang atau melanggar aturan. Karakteristik tersebut menggambarkan kondisi social imature, karena sering menyebabkan terjadinya benturan 
dengan kepentingan, hak orang lain atau nilai-nilai, normanorma dan aturan main yang berlaku dalam lingkungan sosialnya.

Penjelasan di atas memberikan gambaran bahwa orang tua yang memberikan kepercayaan, kebebasan memilih dan mendorong anak untuk mandiri dan percaya diri dapat membantu anak dalam mengembangkan kemampuan sosialnya. Demikianlah peranan pola asuh terhadap perkembangan kematangan sosial anak. Pola asuh atau sikap orang tua tidak hanya mempunyai pengaruh kuat pada hubungan di dalam keluarga tetapi juga pada sikap dan perilaku anak termasuk perilaku mandiri dan kematangan sosial. Orang tua yang tidak terlalu melindungi atau terlalu posesif terhadap anak, mendorong anak untuk mandiri dan percaya diri. Mandiri dan percaya diri merupakan dua kualitas yang sangat mendukung kemampuan sosial anak.

\section{Kesimpulan}

Berdasarkan hasil analisis dan pembahasan dalam penelitian ini maka dapat ditarik kesimpulan sebagai berikut: Ada hubungan negatif yang signifikan antara pola asuh over proteksi orang tua dengan kematangan sosial pada anak PAUD. Mengingat pola asuh orang tua memiliki peran yang sangat penting bagi perkembangan kematangan sosial anak maka diharapkan orang tua lebih dapat mengaplikasikan pola asuh yang baik dan tepat bagi anak, karena pola asuh over proteksi lebih menunjukan pada sikap orang tua yang over protek (perhatian yang berlebihan) terhadap anak sehingga anak tidak mampu mengembangkan potensi kematangan sosialnya dengan baik. Sikap melindungi secara berlebihan akan sangat mempengaruhi dalam kehidupan sehari-hari, karena dalam suatu kehidupan anak itu tidak bisa lepas dari lingkungannya karena akan bisa mudah untuk membentuk kepribadian terhadap anak. Kesempatan dalam beraktualisasi sangat terbatas, sehingga anak kurang memiliki self konfident yang rendah pada setiap aktifitas yang dilakukanya. dampak over proteksi yang dilakukan oleh orang tua terhadap anaknya akan sangat berpengaruh sekali dalam pembentukan perkembangan anak diantaranya: 
1. Anak merasa kurang percaya diri (self konfident) terhadap kemampuan yang dimilikinya, sehingga anak untuk melakukan segala sesuatu kegiatan selalu minta ijin.

2. Sulit untuk menyesuaikan diri terhadap lingkungannya karena tidak terbiasa berhubungan langsung bermain dengan teman-temanya.

3. Akan menjadi penakut dan kepribadian yang labil karena segala apa yang dilakukanya merasa tidak benar.

4. Selalu minta ditemani dalam melaksanakan segala aktifitas, karena anak merasa tidak aman apabila melakukan kegaiatan sendirian.

5. Pertumbuhan kreatifitas yang dimilikinya kurang berkembang dengan baik, karena saat melaksanakan segala kegiatan selalu diatur.

6. Anak akan bereaksi agresif karena ia mendapat hambatan dalam memuaskan keinginannya sebagai akibat dari pola asuh overprotection.

7. Tidak adanya kesempatan pada anak untuk melatih fisik dan gerakkannya padahal hal ini merupakan kesempatan anak untuk menyalurkan keteganggan dan energi yang ada dalam dirinya.

8. Pengasuhan orang tua yang selalu memenuhi tuntutan anak dapat menyebabkan anak sulit dikontrol, kurang bertanggung jawab dan menjadi pemberontak.

9. Anak cenderung memililki konsep diri yang "ngambang" yaitu ketidaktahuan akan diri dan kemampuan yang ia miliki sebagai konsekwensi dari tidak adanya kesepatan untuk mengaktualisasika diri. Konsep diri yang negatif ini akan sangat mempengaruhi keberhasilan anak dalam meraih prestasi. 


\section{Daftar Pustaka}

Atkinson, R., Atkinson, R.C. dan Hilgard, E. R (1993) Pengantar Psikologi Jakarta: Penerbit Erlangga Anggota IKAPI.

Budianto, P. E dkk. 1990 Perbedaan Kematangan Sosial dan Inteligensi dari Anak Kelas I Sekolah Dasar yang melalui Bina Anaprasa dengan yang tidak Melalui Pendidikan Prasekolah. Penelitian: Surabaya, Lab /UPF IImu Kedokteran Jiwa, Fakultas Kedokteran Universitas Airlangga Surabaya

Chaplin, H. (1989) Kamus Psikologi. Jakarta: Penerbit Erlangga.

Daradjat, Z. (1989) Kesehatan Mental. Jakarta: Penerbit PT. Gunung Agung.

Doll.E.A. (1965) Vineland Social Manual of Directors Minessota:American Duidance service. Inc

Goldenberg, I., \& Goldenberg, H. (1985). Family therapy: An overview ( $2^{\text {nd }}$ ed) Belmont, California: Wadsworth, In

Gunarsa, S. D. (1990) Psikologi Perkembangan Anak dan Remaja. Jakarta: PT BPK Gunung Mulia.

Gunarsa. S. D. (1989) Dasar dan Teori Perkembangan Anak. Jakarta: BPK Gunung Mulia

(1986) Pekembangan Anak dan Remaja. Jakarta: BPK Gunung Mulia

Hadi, S. (2000) Statistik Jilid II. Yogyakarta: Penerbit Andi Offset

Halim, M. S. (1994)Penerapan Pola Asuh Orang Tua dan Terjadinya Gangguan Schizophrenia. Laporan Penelitian. Fakultas Psikologi Universitas Katolik ATMAJAYA Jakarta.

Hall, C \& G. Lindzey. (1993). Theories of Personality. New York; John Wiley and Sons. Inc. 
Hurlock, E .B. (1990a) Perkembangan Anak Jilid 1. Edisi VI. Jakarta: Penerbit Erlangga.

(1990b) Perkembangan Anak Jilid 2. Edisi VI. Jakarta: Penerbit Erlangga.

(1990) Psikologi Perkembangan Edisi V. Jakarta: Penerbit Erlangga.

(1997) Psikologi Perkembangan Edisi VI. Jakarta: Penerbit Erlangga.

Johnson, R. C and Medinus, E. R. (1976) Child and Adolescence London: John Wiley and Sons.

Kartono, K. (1985) Peranan Keluarga Memandu Anak. Jakarta CV Rajawali.

Meichati, S. (1978) Kepribadian Mulai Berkembang dalam Keluarga. Yogyakarta: Yayasan Penerbit Fakultas Psikologi Universitas Gadjah Mada

Monks, F. J ; Knoers, A. M. P ; Haditono, S. R (1996) Psikologi Perkembangan: Pengantar dalam berbagai bagiannya. Yogyakarta: Gadjah Mada University Press.

Munandar, S. C.U. (1987) Mengembangkan Bakat dan Kreatifitas Anak Sekolah. Jakarta : PT. Gramedia.

Mussen. M.P.H. ; Conger, J. J ; Kagan, K ; Huston A. C (1992) Perkembangan dan Kepribadian Anak. Edisi 6. Jakarta ; Penerbit ARCAN.

Nuryoto, S. (1992) Kemandirian Remaja Ditinjau Dari Tahap Perkembangan, Jenis Kelamin Dan Peran Jenis. Disertasi. Fakultas Psikologi Universitas Gadjah Mada Yogjakarta. (tidak diterbitkan)

Suryabrata, S. (1989) Metode Penelitian. Jakarta: Rajawali Press. 